\title{
Zastosowania filozofii analitycznej w prawoznawstwie: Wprowadzenie ${ }^{1}$
}

\author{
Pawel Banaś ${ }^{1}$, Wojciech Ciszewski ${ }^{2}$, Adam Dyrda ${ }^{3}$, Bartosz Janik ${ }^{4}$ \\ Uniwersytet Jagielloński w Krakowie \\ 1 pawel.banas@doctoral.uj.edu.pl \\ 2 wojciech.ciszewski@uj.edu.pl \\ 3adam.dyrda@uj.edu.pl \\ ${ }^{4}$ bartosz.janik@doctoral.uj.edu.pl
}

Powiedzieć, że współczesna teoria i filozofia prawa czerpią w znacznej mierze z osiągnięć filozofii analitycznej, to wygłosić pewien komunał. Bez wątpienia zresztą tak zwana ,,analityczna filozofia prawa"2 stanowi wyróżniający się nurt jurysprudencji. Przyczyn takiego stanu rzeczy można wskazać co najmniej kilka.

Po pierwsze, prawo stanowi złożone ontologicznie zjawisko (Lang, Wróblewski, Zawadzki, 1986, s. 32 i n.), które można rozważać na płaszczyźnie językowo-logicznej, socjologicznej, psychologicznej i aksjologicznej. Twierdzenie to wydaje się rozwinięciem intuicji, które nawet nie-prawnicy i nie-filozofowie łączą z prawem. Historycznie to właśnie perspektywa językowo-logiczna pozostawała szczególnie bliska podejściu analitycznemu. Zwraca się tu uwagę na to, że prawo jest formą komunikacji między prawodawcą a podmiotami prawa, a także, że określa ich prawa i obowiązki za pomocą języka. Niemniej współczesna filozofia analityczna interesuje się nie tylko samym językiem, lecz również obszarem naszych przekonań i pragnień, zaś analityczne teorie prawa podkreślają, że prawo stanowi zjawisko społeczne, dostarczając przy tym szczególnych racji czy też motywacji - do działania. Wreszcie samo pojęcie prawa bywało i nadal bywa przedmiotem analizy filozoficznej, która niekiedy służy opisaniu istoty prawa, a kiedy

\footnotetext{
${ }^{1}$ Praca powstała w wyniku realizacji projektu badawczego o $\mathrm{nr}$ 2016/23/N/HS5/00952 finansowanego ze środków Narodowego Centrum Nauki.

${ }^{2}$ Celowo nie używamy pochodzącego z języka angielskiego sformułowania ,analityczna jurysprudencja” (analytical jurisprudence), aby nie sugerować nie do końca uprawnionych skojarzeń z historyczną, XIX-wieczną jurysprudencją analityczną J. Benthama i J. Austina.
} 
indziej związków tego pojęcia z innymi pojęciami, na przykład pojęciem sprawiedliwości i ideą „rządów prawa”. Ponadto na gruncie metodologii analitycznych teorii prawa narzędzia filozofii analitycznej mogą służyć także do odróżnienia oraz wyodrębnienia opisowych i wartościujących (ocennych) twierdzeń teorii dyskutowanych w jej obrębie. Okazuje się, że narzędzia i metody wykształcone przez filozofów analitycznych w XX wieku znajdują istotnie zastosowanie na każdym z tych pól.

Po drugie, fundamentalne dla współczesnej teorii prawa koncepcje pozytywizmu, w tym w szczególności Hartowska teoria pozytywizmu ,wyrafinowanego”, pozostawały pod silnym wpływem analitycznej filozofii ogólnej, zwłaszcza tej uprawianej w duchu filozofii języka potocznego. W rezultacie rozważane w analitycznej filozofii prawa problemy, choć, rzecz jasna, związane z prawem, mają również tradycyjnie charakter ogólnofilozoficzny i są badane przy użyciu typowo filozoficznych narzędzi. W szczególności narzędziem takim pozostaje analiza pojęciowa, czy też, mówiąc bardziej ogólnie (z uwagi na liczne spory o naturę, znaczenie czy rolę analizy pojęciowej) - jakakolwiek systematyczna analiza filozoficzna.

Narzucają się w tym miejscu dwa pytania: pytanie o wspólny mianownik filozofii analitycznej i teorii prawa oraz związane z tym pytanie o to, „co robi właściwie analityczny filozof prawa". Nie są to jednak problemy, których jednoznaczne rozstrzygnięcie (pozytywne lub negatywne) wpływa na możliwość uprawiania filozofii analitycznej w ogóle. W filozofii analitycznej wyróżnić można bowiem całe spektrum stanowisk, z których część promuje tradycyjne („oksfordzkie”) metody analizy pojęciowej, inne proponują istotne rozwinięcie czy modyfikację idei analizy pojęciowej (na przykład w duchu D. Lewisa), a jeszcze inne przejawiają mniej lub bardziej radykalny sceptycyzm wobec możliwości dokonywania analiz pojęciowych jakiegokolwiek rodzaju (jako przykład można wskazać prace W. V. Quine'a, M. G. White'a czy H. Putnama z lat 50. oraz 60. XX wieku). Tego rodzaju rozstrzygnięcia metodologiczne rzutują, rzecz jasna, także na rozstrzygnięcia teoretyczne w ramach analitycznych teorii prawa, choć należy zdawać sobie sprawę, że dany teoretyk może zasadniczo uznawać możliwość dokonywania analiz pojęciowych w bardziej tradycyjnym rozumieniu, a jednocześnie kwestionować możliwość ich zastosowania do rozwiązywania (pewnych) problemów prawnych z uwagi na specyfikę przedmiotu zainteresowania ${ }^{3}$.

Dla filozofii analitycznej był - i, jak się wydaje, ciągle jest - pewnym metodologicznym wyzwaniem tak zwany paradoks analizy (por. Langford, 1942). Podobny problem powstaje, $\mathrm{z}$ całą pewnością, także na gruncie teoretycznoprawnym. Pytanie, w jakich warunkach prowadzone przez teoretyków czy filozofów prawa analizy są jednocześnie informatywne i prawdziwe, pozostaje pytaniem otwartym. Warto jednak nadmienić, że ze względu na wskazany wcześniej wielowymiarowy charakter prawa, a w szczególności z uwagi na jego

\footnotetext{
${ }^{3}$ Tak na przykład zdaje się twierdzić A. Marmor (2013), gdy argumentuje, że pozytywistyczni analityczni filozofowie prawa nie dokonywali właściwie analizy pojęcia prawa, a po prostu dokonywali jego redukcji (por. Banaś, Gołba, 2017).
} 
społeczny, konwencjonalny charakter, analiza pojęcia prawa i pojęć powiązanych znajduje silne umocowanie w potocznych przekonaniach i intuicjach na temat tego, czym prawo jest. Punktem wyjścia dla analizy w prawoznawstwie są zatem w pierwszej kolejności powszechne intuicje i przekonania na temat prawa, które z jednej strony warunkują istnienie prawa jako artefaktu społecznego, a z drugiej stanowią podstawy związanego z nim społecznego „samorozumienia”"4. Oparcie się na tym samorozumieniu nie gwarantuje jeszcze, że teoretyk przeprowadzi poprawną analizę pojęcia prawa, ani, tym bardziej, że skonstruuje przekonującą teorię prawa, bo tych na gruncie zamkniętego zbioru truizmów (to jest powszechnych przekonań i intuicji na temat prawa, budujących owo samorozumienie) można zbudować wiele równie dobrych. Rzecz jasna, w przypadku pojęć pochodzących z języka prawniczego czy prawnego, z dogmatyk prawniczych, bądź znajdujących się po prostu na większym poziomie szczegółowości, wiarygodnym punktem wyjścia dla ich analizy nie będą po prostu powszechne przekonania i intuicje, a raczej przekonania i intuicje podzielane przez grupy eksperckie. Zwracamy na to uwagę, bowiem tym prostym faktem można tłumaczyć to, że analizy pojęć prawnych i prawniczych niejednokrotnie są bardzo hermetyczne. Właśnie dlatego nawet zrozumienie większości ogólnych analiz filozoficznych, nie mówiąc o szczegółowych analizach pojęciowych, może wymagać mimo wszystko pewnego przygotowania i obycia w świecie instytucji prawnych. Samo słynne dzieło H. L. A. Harta pod tytułem Pojęcie prawa (Hart, 1998) było przecież skierowane do ludzi ogólnie wykształconych i prawników, a jego celem była racjonalna rekonstrukcja potocznej teorii prawa, którą w nieuświadomiony sposób zakładała ta lepiej zorientowana część społeczeństwa (Gizbert-Studnicki, Dyrda, Grabowski, 2016, s. 80).

Można przy tym wskazać, że zastosowania filozofii analitycznej w prawoznawstwie mogą być dwojakiego rodzaju: mogą dotyczyć tak zwanej ogólnej teorii prawa (general jurisprudence, Rechtstheorie) oraz tak zwanych szczególnych teorii prawnych, które skupiają się na wybranych aspektach praktyki prawnej czy po prostu - na klaryfikacji bądź analizie pojęć dyskursu prawnego i prawniczego (w tym dogmatyki prawa). Należy jednak zaznaczyć, że analiza filozoficzna w obu przypadkach może dotyczyć zarówno pojęć opisowych, wobec czego dokonanie analizy wymaga jedynie poczynienia pewnych wyborów metodologicznych, jak i pojęć normatywnych, w których przeprowadzenie pełnej analizy niewątpliwie wymaga odwołania się do wartości i ocen o charakterze polityczno-moralnym.

Taka właśnie sfera możliwych związków filozofii analitycznej i prawoznawstwa stanowi kontekst dla rozważań Autorów niniejszego tomu. Warto przy tym dodać, że rozważania te

\footnotetext{
${ }^{4}$ J. Raz pisze: „Pojęcie prawa jako odnoszące się do pewnego typu instytucji społecznych nie jest jednak częścią warsztatu badawczego jakiejkolwiek dyscypliny naukowej. Nie jest to pojęcie wprowadzone przez akademików w celu wyjaśnienia pewnych zjawisk społecznych. Jest to raczej pojęcie zakorzenione w naszym społecznym samorozumieniu. W naszym społeczeństwie jest to pojęcie dość powszechne, a przy tym takie, które nie wywodzi się z żadnej wyspecjalizowanej dyscypliny [...]. Zajmuje ono centralną pozycję, gdy chodzi o nasze rozumienie społeczeństwa, tak naszego własnego, jak i innych. W znacznym stopniu to, co badamy, gdy badamy naturę prawa - to natura naszego samorozumienia [...]. To jest część naszej samoświadomości, sposobu, w jaki pojmujemy i rozumiemy nasze społeczeństwo [...]. Świadomość ta jest częścią tego, co badamy, gdy zgłębiamy naturę prawa" (Raz, 2009, s. 31; por. Gizbert-Studnicki, Dyrda, Grabowski, 2016, s. 81).
} 
w pewnej części stanowiły już przedmiot dyskusji na specjalnych warsztatach pod tytułem „(Granice) zastosowania filozofii analitycznej w prawoznawstwie”, które odbyły się we wrześniu 2017 roku na „Zjeździe Młodych Teoretyków Prawa” w Łagowie. W związku z przeprowadzeniem warsztatów powstał pomysł wydania specjalnego numeru Avant poświęconego tej tematyce. Dziesięć z spośród kilkunastu zaproponowanych tekstów przeszło pozytywnie proces recenzyjny i to one są prezentowane w tym numerze.

Opublikowane artykuły można umieścić w trzech blokach tematycznych: (I) Ogólne problemy prawa i teorii prawa; (II) Szczególne filozoficzne problemy prawa; (III) Prawoznawstwo - etyka - polityka.

W pierwszym bloku tematycznym znajdują się następujące artykuły: artykuł Tomasza Bekrychta pt. Metafizyka pozytywizmu prawniczego $w$ świetle fenomenologii prawa, artykuł Macieja Dybowskiego pt. O intuicji w analitycznych teoriach prawa, artykuł Adama Dyrdy pt. Realizm prawniczy a pozytywizm prawniczy, oraz artykuł Bartosza Biskupa Aporia Phila z perspektywy teorii aktów mowy.

W pierwszym tekście Tomasz Bekrycht dyskutuje dwie z podstawowych tez pozytywizmu prawniczego: tezę o rozdziale prawa i moralności oraz tezę o społecznych źródłach prawa. Inspiracją dla dyskusji tych dwu tez pozytywizmu jest przedstawiona w artykule pod tytułem Metafizyka pozytywizmu prawniczego argumentacja T. Gizbert-Studnickiego (2015), sprowadzająca się między innymi do twierdzenia o tym, że wzrastającemu od ponad dwóch dekad zainteresowaniu metafizyką analityczną w obrębie prawoznawstwa i refleksji nad „naturą" prawa nie towarzyszył żaden zauważalny wpływ tradycji fenomenologicznej. Chcąc niejako uzupełnić tę lukę, Autor przedstawia rozważania fenomenologiczne nad wskazanymi dwoma tezami pozytywizmu. W jego przekonaniu rozważania te stanowią argumenty wspierające pozytywizm jako rozsądną teorię prawa, zaś sama argumentacja o charakterze fenomenologicznym uzupełnia tradycyjnie prowadzone refleksje analityczne.

W drugim z prezentowanych artykułów Maciej Dybowski dokonuje głębszej refleksji i analizy pojęcia intuicji używanego we współczesnych analitycznych teoriach prawa. Podchodzi on krytycznie do deklarowanego przez teorie analityczne oparcia na intuicjach, składających się na tak zwaną potoczną teorię prawa. Jak wskazuje Autor, współczesne analityczne teorie prawa ,zajmują się udzielaniem hermeneutycznej odpowiedzi na metafizyczne pytanie o naturę prawa, a kluczową rolę w realizacji tego zadania pełni intuicja". W dalszej części tekstu Autor wskazuje jednak na różne znaczenia pojęcia intuicji, argumentując między innymi, że analityczni filozofowie prawa rozumieją pojęcie intuicji niejednorodnie, a co za tym idzie, intuicje pełnią różne role w konstrukcji teorii analitycznych i przesądzają o rożnym statusie ich twierdzeń „,metafizycznych”.

W trzecim artykule Adam Dyrda stara się zidentyfikować przyczyny, dla których realizm prawny (szczególnie w wydaniu amerykańskim) jest traktowany jak parias na gruncie współczesnej teorii i filozofii prawa. Zdaniem Autora zasadniczy problem tkwi w powszechnym, lecz błędnym ujęciu relacji między realizmem a ogólnymi teoriami prawa, 
w szczególności zaś pozytywizmem prawniczym. Przy okazji objaśniania tych relacji Autor wskazuje jakie cele przyświecały amerykańskim realistom, gdy próbowali uprawiać pragmatyczną, ametafizyczną i sceptyczną filozofię prawa.

Wreszcie, w ostatnim z tekstów w tym bloku, Bartosz Biskup omawia tak zwaną aporię Phila, znaną też pod nazwą ,zagadki możliwości” (possibility puzzle), która stanowi teoretycznoprawny, bo dotyczący zjawiska performatywności i normatywności prawa, odpowiednik dylematu jajko-kura. Z jednej strony można bowiem twierdzić, że prawodawca może ustanowić normę prawną tylko wtedy, gdy jakaś inna norma daje mu odpowiednią kompetencję; z drugiej strony norma nadająca tę kompetencję może istnieć tylko o tyle, o ile ktoś ją skutecznie ustanowił. Autor rozważa wskazany problem w kontekście dwóch dostępnych rodzajów teorii: konwencjonalizmu i nonkonwencjonalizmu aktów mowy, argumentując, że problem powstaje tylko przy założeniu, że akt mowy Pierwszego Legislatora był aktem konwencjonalnym.

W drugim bloku znajdują się następujące artykuły: artykuł Izabeli Skoczeń pt. Rozstrzyganie sporów w oparciu o zasady dobra i stuszności versus orzekanie $w$,,trudnych przypadkach" w świetle wspótczesnych koncepcji metaetycznych, artykuł Szymona Osmoli pt. Między obietnica a umowa. Granice zastosowania filozoficznego dyskursu o obietnicach $w$ teorii prawa kontraktowego oraz artykuł Szymona Mazurkiewicza pt. Czy natura człowieka może być podstawa praw człowieka? Ujęcie analityczne.

Pierwszy artykuł, autorstwa Izabeli Skoczeń, jest analizą reguły rozstrzygania sporów prawnych w oparciu o zasady dobra i słuszności. Zasadniczym celem Autorki jest pokazanie, że zarzuty subiektywizmu i relatywizmu, które formułuje się wobec orzekania na podstawie tych zasad, mogą być skutecznie odpierane w sytuacji, gdy zasady te zinterpretujemy ekspresywistycznie. Autorka w kolejnych częściach pracy rozważa możliwe podobieństwa pomiędzy rozstrzyganiem sporów w oparciu o zasady dobra i słuszności a orzekaniem w ramach tak zwanych ,trudnych przypadków”, przedstawia niezbędne pojęcia metaetyczne oraz uzupełnia informacje doktrynalne dotyczące omawianych zasad tak, aby ostatecznie pokazać właściwe odczytanie rozumowań opierających się na zasadach dobra i słuszności, które umożliwia uporanie się z problemami obiektywizmu i relatywizmu.

Artykuł Szymona Osmoli dyskutuje możliwości zastosowania ustaleń analitycznej filozofii obietnic na gruncie teorii prawa. Artykuł stanowi wszechstronne przedstawienie filozoficznych dyskusji dotyczących pojęcia obietnicy, z naciskiem na prezentację koncepcji umowy jako obietnicy oraz jej formalnej i materialnej krytyki. Autor prezentuje zasadnicze stanowiska w dyskusji oraz wskazuje na ich mocne i słabe strony, po czym przechodzi do rozważań dotyczących możliwości aplikacji ustaleń czysto filozoficznej debaty dotyczącej obietnic na grunt teorii prawa. Okazuje się, że specyfika rozważań teoretycznoprawnych sprawia, iż przedsięwzięcie to jest w wysokim stopniu skomplikowane i otwiera olbrzymią przestrzeń dla nowych problemów. 
Artykuł Szymona Mazurkiewicza zajmuje się analizą metafizycznych fundamentów, na których opierają się prawa człowieka. Autor rozważa tezę, że tym fundamentem jest natura człowieka. Autor dzieli zagadnienie na kilka problemów szczegółowych i dokonuje ich systematycznej analizy. Przede wszystkim zajmuje się problemem definicji „,natury (obiektu) X”. Przeprowadza on filozoficzną oraz teoretycznoprawną analizę tego pojęcia, która stanowi punkt wyjścia dla dalszej analizy możliwości zastosowania pojęcia natury człowieka do określenia fundamentu praw człowieka. Autor twierdzi, że ujęciem natury człowieka, które umożliwia uznanie jej za fundament praw człowieka, jest ujęcie jej jako opisowo rozumianej tendencji w zachowaniach. Co więcej, przy takim ujęciu natury człowieka możliwa jest naturalizacja metodologiczna zasadniczych elementów dyskusji dotyczącej praw człowieka.

Wreszcie w trzecim bloku znajdują się trzy artykuły: artykuł Katarzyny Eliasz pt. Krytyka neorepublikańskiej koncepcji wolności politycznej Philipa Pettita, artykuł Wojciecha Ciszewskiego pt. Czy demokracja to rządy większości wyłonionej w wyborach? oraz artykut Marty Dubowskiej pt. Praktyczny konstytucjonalizm federalisty Publiusa i jego filozoficzne podstawy.

Artykuł Katarzyny Eliasz stanowi wnikliwe omówienie jednego z najważniejszych ujęć wolności politycznej, to jest koncepcji wolności rozumianej jako nieobecność dominacji. Zgodnie z tą koncepcją obywatel jest wolny, o ile nikt nie sprawuje nad nim arbitralnej władzy. Rozumienie wolności jako nie-dominacji jest szczególnie popularne na gruncie współczesnego instrumentalnego republikanizmu. Opierając się na pracach P. Pettita, a także innych przedstawicieli tego nurtu filozofii politycznej, Katarzyna Eliasz rekonstruuje koncepcję wolności jako nie-dominacji, a następnie wysuwa pod jej adresem kilka zarzutów. Zdaniem Autorki jednym z głównych problemów tej koncepcji jest ograniczenie doniosłości wolności politycznej. Powołując się między innymi na prace H. Arendt oraz A.de Tocqueville'a, Katarzyna Eliasz zwraca uwagę na to, że wolność, poza wymiarem instrumentalnym, na którym koncentruje się Pettit, może mieć również istotne znaczenie dla dobrego życia jednostek (jako wartość konstytutywna dobrego życia), a także pełnić istotną rolę z punktu widzenia systemu demokratycznego (ponieważ ogranicza niektóre słabości tego systemu).

Tekst Wojciecha Ciszewskiego odnosi się do współczesnego sporu o treść pojęcia demokracji. Autor podejmuje polemikę z jednym z najpopularniejszych ujęć demokracji, to jest koncepcją demokracji minimalnej, a punktem wyjścia do tej polemiki są rozważania J. Schumpetera. Jak twierdzi Wojciech Ciszewski, Schumpeterowskie rozumienie systemu demokratycznego możemy sprowadzić do zasady rządów większości wyłonionej w cyklicznych wyborach powszechnych. Autor artykułu wskazuje na liczne słabości tak ujmowanej koncepcji - według niego wspomniana zasada nie jest ani koniecznym, ani wystarczającym warunkiem uznania danego ustroju politycznego za demokratyczny. Zdaniem Autora pojęcie demokracji jest szersze - obejmuje ono bowiem katalog wartości demokratycznych związanych z ideą obywatelstwa demokratycznego, szczególnymi warunkami działania politycznego, a także z ograniczeniami władzy w systemie demokratycznym. 
Marta Dubowska w swoim artykule omawia natomiast specyfikę historycznego dyskursu wokół Konstytucji Stanów Zjednoczonych. Głównym przedmiotem zainteresowania Marty Dubowskiej są argumenty, jakie formułowali autorzy Federalisty posługujący się pseudonimem „Publius”, czyli A. Hamilton, J. Madison i J. Jay. Autorka artykułu przedstawia historyczne okoliczności powstania Federalisty, a następnie dokonuje analizy filozoficznych założeń tego dzieła. Wskazuje w szczególności na dwie inspiracje filozoficzne, które miały zasadnicze znaczenie dla argumentacji przedstawionej przez Publiusa, to jest koncepcje J. Locke'a oraz D. Hume'a. Zdaniem Autorki nie jesteśmy w stanie trafnie oceniać zasadności poszczególnych racji oraz postulatów zgłaszanych w debacie konstytucyjnej, jeżeli nie rozumiemy ich filozoficznych podstaw.

Jako redaktorzy tego tomu żywimy nadzieję, że zamieszczone w nim artykuły sprowokują czytelników do analitycznej refleksji i krytyki. Czymże bowiem jest filozofia, jeśli nie uporczywym zadawaniem pytań i ciągłym podważaniem odpowiedzi nań udzielanych?

\section{Bibliografia}

Banaś P., Gołba, F. (2017). Canberra-style analysis and law: A critique of Andrei Marmor's farewell to conceptual analysis, Ratio Juris, 30(4), 549-559.

Langford, C. H. (1942). The notion of analysis in Moore's philosophy. W: P. A. Schilpp (red.), The philosophy of G. E. Moore, Evanston: Northwestern University.

Gizbert-Studnicki, T. (2015). Metafizyka pozytywizmu prawniczego. Principia, 61-62, 19-40.

Gizbert-Studnicki, T., Dyrda, A., Grabowski, A. (2016). Metodologiczne dychotomie: Krytyka pozytywistycznych teorii prawa, Warszawa: Wolters Kluwer.

Hart, H. L. A. (1998). Pojęcie prawa. (J. Woleński, thum.). Warszawa: Wydawnictwo Naukowe PWN.

Marmor, A. (2013). Farewell to conceptual analysis (in jurisprudence). W: W. Waluchow, S. Sciaraffa (red.), Philosophical foundations of the nature of law (s. 209-229). Oxford, UK: Oxford University Press.

Raz J. (2009). Can there be a theory of law. W: W. Waluchow, S. Sciaraffa (red.), Between authority and interpretation: On the theory of law and practical reason. Oxford, UK: Oxford University Press.

Wróblewski, J., Lang, J., Zawadzki, S. (1986). Teoria państwa i prawa. Warszawa: Państwowe Wydawnictwo Naukowe. 